\title{
Paper Birch and European White Birch Vary in Growth and Resistance to Bronze Birch Borer
}

\author{
Raymond O. Miller, Paul D. Bloese, James W. Hanover \\ Department of Forestry, Michigan State University, East Lansing, MI 48824 \\ Robert A. Haack \\ U.S. Department of Agriculture Forest Service, North Central Forest Experiment Station, 1407 S. \\ Harrison Road, East Lansing, MI 48823
}

\begin{abstract}
Additional index words. Betula papyrrfera, Betula pendula, Agrilus anxius, narrow-sense heritability, selection, correlated traits

Abstract. A test of Michigan half-sib progeny of paper birch (Betula papyrifera Marsh.) and European white birch (B. pendula Roth.) was conducted in Michigan to examine species variation in growth, bark color, and resistance to bronze birch borer (Agrilus anxius Gory). Paper birch was superior to European white birch in height and borer resistance at age 12 years from seed. Families of paper birch were identified that grew exceptionally well, had developed white bark within 6 years, and exhibited borer resistance. The magnitude of additive genetic variance and narrow-sense family heritability estimates for paper birch indicated that sufficient genetic variation and inheritance exist to support selection and breeding for height. Paper birch may be an acceptable substitute for European white birch as a landscape species in northeastern North America.
\end{abstract}

White-barked birches are ecologically and economically important in North America. They exist on a variety of sites and are used by the forest industry for products ranging from furniture and toothpicks to paper and firewood (Panshin and deZeeuw, 1980). Some of the white-barked birches have unique tolerances that allow them to be used on land reclamation sites and on marginal sites that are too wet, dry, or close to air pollution sources for other tree species (Clausen, 1968). One of the highest economic values of birches, however, is as a landscape tree.

Urban and suburban landscape sites are often extensively graded and compacted. These and other factors, such as drought, frequently stress trees, predisposing them to a range of insect and disease pests (Mattson and Haack, 1987). It is under stressed conditions that birches often exhibit dieback as a result of infestation by the bronze birch borer Agrilus anxius (Coleoptera: Buprestidae).

The bronze birch borer was first described in the late 1800s as a pest, usually secondary, of grey birch (Betula populifolia Marsh.), sweet birch (B. lenta L.), yellow birch (B. allegheniensis Britt .), paper birch (B. papyrifera Marsh.), and European white birch (B. pendula Roth.), and has since been found to attack almost all species in the genus Betula (Anderson, 1944; Wilson and Haack, 1990). European white birch is the principal host in urban landscape plantings (Ball and Simmons, 1986). Although this borer can use many birch species as a host, there are numerous reports that some species are more resistant than others. For example, paper birch, river birch (B. nigra L.), Monarch birch (B. maximowicziana Regal), and Japanese birches [B. mandshumca Miquel and B. platyphylla var. japonica (Miq.) Hara] have shown resistance (Ball and Simmons, 1980; Kozel and Smith, 1976; Kozel and Toth, 1975).

Most of the interspecific comparisons regarding borer resis-

Received for publication 5 Apr. 1989. Michigan Agricultural Experiment Station Paper no. 12733. We thank the staff of Michigan State Univ.'s Russ Forest for their help with plantation maintenance and data collection. We also thank Daniel Keathley and Gary Simmons for their review of an earlier version of this manuscript. The cost of publishing this paper was defrayed in part by the payment of page charges. Under postal regulations, this paper therefore must be hereby marked advertisement solely to indicate this fact. tance have been based on observations in arboreta or isolated ornamental specimens, and many are based on young seedlings or saplings. Reports of these observations are often conflicting. For example, grey birch is listed by Kozel and Toth (1975) as highly susceptible to borer attack based on observations of isolated trees, yet Dirr (1981) presents a list of resistant species that includes grey birch and does not mention Kozel and Toth's admonition. When Santamour (1982) tested several birch species, he found that grey birch demonstrated some resistance to the borer. In another test, Japanese white birch $(B$. platyphylla var. japonica) had the largest and most vigorous trees and appeared highly resistant to borer early in its testing (Santamour and Clausen, 1979). By the 10th year of the test, however, all but one of the original 127 trees had died due to borer attack (Santamour, 1982). Nevertheless, a seed source of Japanese white birch named "whitespire" was reported as borer resistant 3 years later (Reed, 1985). These ostensibly conflicting reports may simply reflect natural intraspecific genetic variation and point to the need for extensive sampling of a tree species' natural population to more accurately and fully characterize the range of a species' performance.

Extensive genetic testing of North American birch provenances and families has only been reported for yellow birch (Clausen and Garrett, 1969). These tests reported significant variation in all traits measured, including growth rate, time of spring flushing, and leaf morphology. Significant variation was found among and within provenances. Significant intraspecific variation in growth has also been reported for paper birch and European white birch in a small test in Vermont (Hannah, 1987). It should, therefore, be possible to identify and capture natural variation within these species for a wide range of characters using standard tree improvement techniques.

The study reported here was designed to test an extensive sample of Michigan half-sib families of paper birch on a single site and to thereby estimate the expected range of performance of this species in southern Michigan and similar environmental conditions. The plantation presently serves as a genetic archive and provides material for the vegetative propagation of interesting genotypes. European white birch half-sib families were originally included in the test to provide a comparison with the native species. 


\section{Materials and Methods}

Test establishment. Seed from 201 half-sib families of paper birch was collected in Michigan, with 119 families collected from Michigan's Upper Peninsula and 82 families collected from the northern Lower Peninsula. Fifteen half-sib families of European white birch were also included in the test. Ten of these seedlots originated in Finland, while the remaining five came from interprovenance crosses between Finnish sources (used as male parents) and Polish, Norwegian, Czechoslovakian, and Latvian sources (used as female parents). Finnish sources have demonstrated acceptable survival and growth in Vermont 6 years after outplanting (Hannah, 1987).

All seedlots were sown in Feb. 1976 in plastic-coated paper plant bands $(5 \times 5 \times 27 \mathrm{~cm})$ filled with a mix of 3 peat : 1 perlite : 1 vermiculite (by volume). Seedlings were grown in the greenhouse for 5 months, held outdoors for 2 weeks, and then planted, with bands removed, in a plowed and disked field in June 1976. Trees were planted on $2.4 \times 2.4 \mathrm{~m}$ square spacing in a completely randomized design with an average of five trees per half-sib family (ranging from a maximum of seven to a minimum of three trees per family). Weeds were controlled with periodic mowing and broadcast application of $4.5 \mathrm{~kg}$ ail ha linuron in Apr. 1977, before the seedlings had broken dormancy.

Measurement and analysis. Measurement of this material began while it was still in the greenhouse (these data have been thoroughly summarized by Sohasky, 1977) and continued through 1988. Height, diameter, bark color, borer damage, and tree survival were measured at varying intervals over 12 years. Height was measured in years 2,6 , and 10 post-establishment (abbreviated as HT.2, HT.6, and HT. 10, respectively). Diameter was measured at breast height in year 7 (DBH.7). Bark color was scored in years 6 and 8 (BARK.6 and BARK.8) on a scale of 0 to 2 , with $0=$ reddish-brown; $1=$ changing to white; and $2=$ white. Borer damage was evaluated in years 10 and 12 (BORER.10 and BORER.12) on a scale of 0 to 3 , with $0=$ no evidence of borer infestation; 1 = less than half of crown branches dead or dying, with borer-related bark ridges obvious; $2=$ more than half of crown dead or dying, with bark ridges obvious and borer exit holes often present; and $3=$ tree dead with bark ridges present and borer exit holes usually present. Bark ridges (callus tissue) occur on branch and trunk sections in response to larval feeding by the borer (Anderson, 1944; Wilson and Haack, 1990). The presence of borer-related bark ridges was scored in year 12 (RIDGES.12). Completion of larval development was also scored in year 12 by noting the presence of borer exit holes (EXITS. 12). Survival was computed in years $2,6,8,10$, and 12 as a percentage of the total number of trees initially planted (SURVIVAL.2, SURVIVAL.6, SURVIVAL.8, SURVIVAL.10, and SURVIVAL.12).

Only height and diameter data were normally distributed. All the BARK and BORER variables were skewed due to strong differences in species performance, while the RIDGES .12 and EXITS. 12 data followed a binomial distribution. $t$ tests were computed for differences in growth traits (height and diameter) between species and between the paper birch progenies originating from the Upper and Lower Peninsulas of Michigan. Since bark color and borer variables were not normally distributed, differences between species'means and means of Upper and Lower Peninsula paper birch progenies were tested using the Mann-Whitney two-sample test, which is a nonparametric anslog of the $t$ test. Interspecific and interpeninsular differences in survival were examined via $x^{2}$ tests. The NPARIWAY pro- cedure of the SAS statistical package was used for the computation of all nonparametric tests and the SAS TTEST procedure for all parametric t tests (SAS, 1985).

Analyses of variance (ANOVA) were used to test for intraspecific differences among seedlots for height and diameter for both birch species. The Kruskal-Wallis nonparametric ANOVA was used to test for intraspecific seedlot differences for bark color and borer variables. The GLM procedure of the SAS statistical package was used for all parametric ANOVAs (SAS, 1985).

ANOVAs in family height growth 10 years from seed were performed separately for paper and European white birch, using only families that were represented by two or more individuals (thereby including 14 families of European white birch and 174 families of paper birch in the analyses). These analyses were used to detect differences among half-sib families within each species and to estimate additive genetic variance and narrowsense family heritability. The format of the ANOVAs is given in Table 1. Family $\left(\mathrm{V}_{\mathrm{f}}\right)$ and error $\left(\mathrm{V}_{\mathrm{e}}\right)$ variance components were estimated by equating the expected mean squares given in Table 1 to the observed mean squares produced from the analyses and solving for $\mathrm{V}_{\mathrm{f}}$ and $\mathrm{V}_{\mathrm{e}}$. Narrow-sense family heritability $\left(h_{\mathrm{f}}{ }^{2}\right)$ was estimated for 10th-year height and 7th-year diameter for both species using the following formula: $h_{\mathrm{f}}^{2}=\mathrm{V}_{\mathrm{f}} /\left(\mathrm{V}_{\mathrm{e}} / \mathrm{N}+\right.$ $\mathrm{V}_{\mathrm{f}}$ ), where $\mathrm{N}$ equals the average number of surviving trees per family $(\mathrm{N}=3.4$ and 2.6 for paper birch and European white birch, respectively, at year 10). The variance component and heritability estimation procedures described above follow Wright's (1976) guidelines.

Since this test was established on a single site, the heritability estimates produced from these analyses may be inflated due to the inability of single-site analyses to partition the family $\mathrm{x}$ environment variance component from the family variance component $\left(\mathrm{V}_{\mathrm{f}}\right)$. This results in an inflated estimate of $\mathrm{V}_{\mathrm{f}}$ if the interaction term is significant. Additionally, the limited number of progeny per half-sib family diminishes the precision of variance component and heritability estimates. Therefore, the heritability estimates reported here should be viewed as initial baseline information and only used as a rough guide to the species' performance in southern Michigan or comparable environments.

Simple correlations were performed among the measured traits to detect linear relationships for each birch species. Factor analysis was performed on the whole data set (both species combined) to further examine these relationships. Correlations and factor analysis were computed using the Number Cruncher Statistical System (Hintze, 1987). These relationships were interpreted for their implications to tree improvement and breeding systems for white birches.

\section{Results and Discussion}

Variation between and within species. The average performante of seedlots is summarized in Table 2. Paper birch was significantly superior to European white birch in all growth traits

Table 1. Format of the ANOVAs used to estimate variance components for 10-year height of half-sib families of paper and European white birch.

\begin{tabular}{llc}
\hline \hline Source & \multicolumn{1}{c}{$\mathrm{df}^{\mathrm{z}}$} & Expected mean squares $^{y}$ \\
\hline Family & $\mathrm{F}-1$ & $\mathrm{~V}_{\mathrm{e}}+\mathrm{N} \mathrm{V}_{\mathrm{f}}$ \\
Error & $\mathrm{F}(\mathrm{N}-1)$ & $\mathrm{V}_{\mathrm{e}}$ \\
\hline
\end{tabular}

${ }^{2} \overline{\mathrm{F}}=$ no. families for each species.

${ }^{y} \mathrm{~N}=$ average no. trees per half-sib family for each species. 
Table 2. Mean performance of white birch in a half-sib progeny test in southern Michigan.

\begin{tabular}{|c|c|c|c|c|c|c|c|}
\hline \multirow[b]{3}{*}{$\begin{array}{l}\text { Measured } \\
\text { traits }^{2}\end{array}$} & \multirow[b]{3}{*}{ Units } & \multicolumn{2}{|c|}{ Species $^{\mathbf{y}}$} & \multicolumn{4}{|c|}{ Paper birch ${ }^{y}$} \\
\hline & & \multirow{2}{*}{$\begin{array}{c}\text { European } \\
\text { white } \\
\text { birch }\end{array}$} & \multirow[b]{2}{*}{$\begin{array}{l}\text { Paper } \\
\text { birch }\end{array}$} & \multirow[b]{2}{*}{$\begin{array}{c}\text { Lower } \\
\text { Peninsula }\end{array}$} & \multirow[b]{2}{*}{$\begin{array}{c}\begin{array}{c}\text { Upper } \\
\text { Peninsula }\end{array} \\
\end{array}$} & \multicolumn{2}{|c|}{ Family \#207 } \\
\hline & & & & & & $\begin{array}{l}\text { Fam. } \\
\text { avg. }\end{array}$ & $\begin{array}{c}\text { Best } \\
\text { individual }\end{array}$ \\
\hline \multicolumn{8}{|c|}{ Growth traits } \\
\hline HT.2 & $\mathrm{cm}$ & $62 \mathrm{~b}$ & $93 \mathrm{a}$ & $101 \mathrm{a}$ & $87 \mathrm{~b}$ & 132 & 175 \\
\hline HT.6 & $\mathrm{cm}$ & $228 \mathrm{~b}$ & $316 \mathrm{a}$ & $352 \mathrm{a}$ & $290 \mathrm{~b}$ & 462 & 503 \\
\hline HT.10 & $\mathrm{cm}$ & $562 \mathrm{~b}$ & $622 \mathrm{a}$ & $698 \mathrm{a}$ & $566 \mathrm{~b}$ & 907 & 1030 \\
\hline DBH.7 & $\mathrm{cm}$ & $9 \mathrm{a}$ & $9 \mathrm{a}$ & $10 \mathrm{a}$ & $8 \mathrm{~b}$ & 14 & 15 \\
\hline \multicolumn{8}{|c|}{ Bark color } \\
\hline BARK. 6 & $0-2$ & $1.3 \mathrm{a}$ & $0.7 \mathrm{~b}$ & $0.8 \mathrm{a}$ & $0.5 \mathrm{~b}$ & 0.7 & 1.0 \\
\hline BARK. 8 & $0-2$ & $1.4 \mathrm{a}$ & $0.9 \mathrm{~b}$ & $1.0 \mathrm{a}$ & $0.9 \mathrm{~b}$ & 1.3 & 2.0 \\
\hline \multicolumn{8}{|c|}{ Bronze birch borer damage } \\
\hline BORER.10 & $0-3$ & $2.5 \mathrm{a}$ & $0.5 \mathrm{~b}$ & $0.4 \mathrm{a}$ & $0.6 \mathrm{a}$ & 0.0 & 0.0 \\
\hline BORER.12 & $0-3$ & $2.9 \mathrm{a}$ & $0.6 \mathrm{~b}$ & $0.4 \mathrm{a}$ & $0.8 \mathrm{a}$ & 0.0 & 0.0 \\
\hline RIDGES.12 & $0-1$ & $1.0 \mathrm{a}$ & $0.4 \mathrm{~b}$ & $0.3 \mathrm{~b}$ & $0.5 \mathrm{a}$ & 0.0 & 0.0 \\
\hline EXITS.12 & $0-1$ & $1.0 \mathrm{a}$ & $0.2 \mathrm{~b}$ & $0.1 \mathrm{a}$ & $0.2 \mathrm{a}$ & 0.0 & 0.0 \\
\hline \multicolumn{8}{|c|}{ Survival } \\
\hline SURVIVAL.2 & $\%$ & $56 \mathrm{a}$ & $63 a$ & $62 \mathrm{a}$ & $64 \mathrm{a}$ & 60 &.-- \\
\hline SURVIVAL. 6 & $\%$ & $53 a$ & 62 a & $61 \mathrm{a}$ & $63 \mathrm{a}$ & 60 &.-- \\
\hline SURVIVAL.8 & $\%$ & $49 \mathrm{~b}$ & $61 \mathrm{a}$ & $61 \mathrm{a}$ & $62 \mathrm{a}$ & 60 & --- \\
\hline SURVIVAL.10 & $\%$ & $15 \mathrm{~b}$ & $56 \mathrm{a}$ & $58 \mathrm{a}$ & $55 \mathrm{a}$ & 60 & $\cdots$ \\
\hline SURVIVAL.12 & $\%$ & $1 \mathrm{~b}$ & $50 \mathrm{a}$ & $55 \mathrm{a}$ & $47 \mathrm{~b}$ & 60 & -- \\
\hline $\mathrm{N}^{\mathrm{x}}$ & Trees & 154 & 1078 & 441 & 637 & 5 & $\cdots$ \\
\hline
\end{tabular}

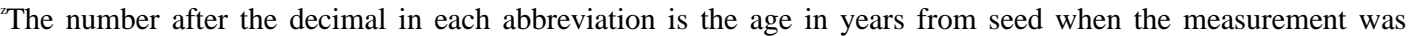
made; see text for details.

'Means followed by the same letter (within rows, separately for the two birch species and for Lower vs. Upper Peninsula sources of paper birch) are not significantly different at $P<0.05$. Mean separation by t test for growth traits, Mann-Whitney two-sample test for bark and borer variables, and $\mathrm{x}^{2}$ for survival.

${ }^{\times}$No. trees originally planted.

except diameter at age 7 , where they were equal $(P>0.05)$. Paper birch from the Lower Peninsula was superior to that from the Upper Peninsula for all growth traits. ANOVAs (both standard and Kruskal-Wallis) showed significant $(P<0.01)$ intraspecific differences among paper birch seedlots for all growth, bark color, and borer variables. In contrast, only 10th-year height varied significantly $(P<0.05)$ among seedlots of European white birch.

European white birch was heavily damaged by bronze birch borer by ages 10 and 12 (Table 2). Mean scores for all borerrelated factors were near the maximum values for European white birch, with very little variability observed. Of the 82 European white birch trees originally planted, only 12 were alive at the end of the growing season in year 10, and only 1 was alive in year 12. As previously reported, European white birch is unquestionably susceptible to this lethal pest (Ball and Simmons, 1986). Mortality due to bronze birch borer damage is the principal cause of reduced survival of European white birch (1\%) compared to paper birch (50\%) at age 12 (Table 2).

Paper birch performed quite well with respect to borer damage, averaging 0.5 to 0.6 on a scale of 0 to 3 (Table 2). Variability within the species was large, with half-sib family means ranging from 0 to 3 for borer damage. Dirr (1981) noted the contradictory reports about paper birch's resistance to the borer, and suggested that the confusion may have resulted from tree misidentification by various observers. This study suggests that the confusion may simply result from intraspecific variation in borer resistance, and points to the risks incurred when attempting to characterize an entire species based on the performance of a limited sample. Although the test reported here contains small samples of each of the half-sib families (averaging 3.4 trees per family), it does represent an extensive sample (174 half-sib families) of Michigan's natural paper birch population, and should give a reasonable indication of the range of the Michigan paper birch population's response to bronze birch borer attack.

One of the principal reasons European white birch is used for landscaping is that its bark turns white at an earlier age than paper birch. Bark color observations made here at age 6 support this claim. Based on species means, European white birch was significantly $(P<0.01)$ whiter than paper birch at ages 6 and 8 years (Table 2). However, considerable variation in bark color existed among paper birch seedlots, with family means ranging from 0 to 1.5 (on a scale of 0 to 2 , with 2 being white) at age 6 . In addition, by age 6, 21 paper birch families equaled or surpassed the European white birch species mean for white bark color.

The disadvantage of European white birch is clear: it is extremely susceptible to, and intolerant of, bronze birch borer attack. Recognition of this shortcoming has spurred horticulturists to seek borer-resistant species or cultivars that can match European white birch's rapid growth, white bark, and pleasing fall foliage coloration. One approach commonly adopted is to search for an entire species that meets these requirements, but this has often led to inconclusive and ambiguous results. Another approach, and the one supported by findings in this study, involves an extensive screening within a species to find families and individuals with the correct combination of desirable traits.

Paper birch family 207, from Arenac County in the Lower Peninsula of Michigan, is an example of such a family (Table 
2). At age 10, family $207(\mathrm{~N}=3$ trees $)$ averaged $>9 \mathrm{~m}$ tall and exhibited no evidence of borer attack. It had a bark color score equivalent to the species average for European white birch at age 8 , and the best individual in family 207 had all-white bark at that age. Other families combining above-average growth, bark color, and borer resistance were also found in this test. Although confirmation of the genetic superiority of family 207, and other similarly performing families, is tempered by their limited sample size, their performance is indicative of the range of variability in paper birch, and substantiates the potential value of future selection efforts.

An ANOVA in 10th-year height growth indicates the extent of genetic variability within both species (Table 3). Significant differences were detected among seedlots of paper birch and European white birch $(P<0.001$ and $\mathrm{P}<0.05$, respectively). Although heritabilities and genetic variance components are probably overestimated due to the inability to estimate family $x$ environment interaction from single-site data, they still indicate that sufficient genetic variation and inheritance exist to support intensive selection and breeding for height. While rapid height growth may not usually be a primary concern in urban and suburban landscape plantings, in the case of paper birch it could gain importance, as correlations reported below indicate it is positively correlated with the early development of white bark.

Relationships among measured traits. An understanding of the relationships among traits is requisite to the success of a breeding program that seeks to combine them. In general, growth traits were negatively correlated with borer damage for paper birch but were uncorrelated or poorly correlated for European white birch (Table 4). Thus, selection of large trees will not necessarily predispose selected stock to borer attack. The slight

Table 3. ANOVA and narrow-sense family heritability estimates $\left(h_{f}^{2}\right)$ for 10-year height of half-sib families of paper and European white birch.

\begin{tabular}{|c|c|c|c|c|c|}
\hline Source & df & Mean square & $F$ value & $P>\mathrm{F}$ & $h_{f}^{2}$ \\
\hline $\begin{array}{l}\text { Family } \\
\text { Error }\end{array}$ & $\begin{array}{l}174 \\
423\end{array}$ & $\begin{array}{l}\text { Paper b } \\
68,982 \\
43,520\end{array}$ & 1.59 & 0.001 & 0.37 \\
\hline $\begin{array}{l}\text { Family } \\
\text { Error }\end{array}$ & $\begin{array}{r}9 \\
16 \\
\end{array}$ & $\begin{array}{c}\text { European wh } \\
35,302 \\
12,076 \\
\end{array}$ & $\begin{array}{r}\text { birch } \\
2.92\end{array}$ & 0.05 & 0.66 \\
\hline
\end{tabular}

negative correlation between growth traits and borer damage for paper birch (most evident for height at age 10), suggests that the larger, more vigorous trees were able to limit larval feeding or that adult beetles laid fewer eggs on such trees.

Bark color in both birch species was positively correlated with growth characteristics and uncorrelated with borer damage (Table 4). Selecting larger trees should have the effect of improving bark color, i.e., whiter bark at an earlier age.

The growth traits were all positively correlated with one another, except for age 2 height of European white birch, which was not correlated with any of the measured traits (Table 4). Strong positive correlations existed among height at 6 years and the other growth traits, which indicates that selection for growth can be made confidently at age 6 .

A correlation of 1.0 was found between the occurrence of bark ridges on the stem (the tree's response to larval boring) and the presence of exit holes on European white birch (Table 4). The corresponding correlation in paper birch was only 0.5 . Tree resistance to insects may be due to a variety of factors affecting insect ovipositing, feeding, development, and emergence. These factors can be chemical, morphological, nutritional, and physiological and operate at each stage of the insect's development (Hanover, 1975). Ball and Simmons (1980, 1986) reported that larval development and adult emergence are often impeded in healthy birch, but that the insect could develop normally on European white birch in any stage of health. The correlations reported above support the observation for European white birch that once the tree is attacked, borer larvae are usually able to complete development. In contrast, when paper birch is attacked, there is a high probability that the attacks will be unsuccessful (i.e., bark ridges produced, but no borer exit holes).

Factor analysis confirmed the interpretation of the univariate correlations (Table 5). The majority of variation in the data can be explained with the first three factors, which combine the effects of the measured variables in a way consistent with the previous discussion. Factor 1 combines the various growth traits and accounts for the largest portion of the variability. Factor 2 combines the effects of borer damage variables. Factor 3 is composed almost exclusively of bark color at age 6 , and is the last factor to contribute substantially to the analysis. Bark color accounts for a minimal proportion of the total variation in the data, when compared to growth and borer resistance.

Throughout eastern North America, which is the range of the

Table 4. Simple correlations among measured traits in a progeny test of white birches in southern Michigan. Paper birch correlations appear above diagonal and European white birch below diagonal. Paper birch correlations greater than \pm 0.25 are significant at $P<0.01$. European white birch correlations must exceed \pm 0.40 for significance at $P$ $<0.01$. Traits described in detail in text.

\begin{tabular}{|c|c|c|c|c|c|c|c|c|c|c|}
\hline Trait & HT.2 & HT.6 & HT. 10 & DBH.7 & BARK.6 & BARK. 8 & BORER.10 & BORER.12 & RIDGES.12 & EXITS.12 \\
\hline \multicolumn{11}{|c|}{ Paper birch } \\
\hline HT.2 & --- & 0.66 & 0.54 & 0.60 & $0.40^{2}$ & 0.46 & -0.04 & -0.13 & -0.14 & -0.08 \\
\hline HT.6 & 0.34 & $--\cdot$ & 0.89 & 0.92 & 0.60 & 0.63 & -0.11 & -0.24 & -0.26 & -0.15 \\
\hline HT.10 & 0.26 & 0.74 & --- & 0.90 & 0.58 & 0.63 & -0.29 & -0.41 & -0.40 & -0.29 \\
\hline DBH. 7 & 0.34 & 0.96 & 0.77 & --- & 0.61 & 0.61 & -0.19 & -0.31 & -0.32 & -0.21 \\
\hline BARK. 6 & 0.40 & 0.73 & 0.54 & 0.67 & -- & 0.63 & -0.13 & -0.20 & -0.22 & -0.13 \\
\hline BARK. 8 & 0.12 & 0.54 & 0.52 & 0.54 & 0.50 & --- & -0.05 & -0.16 & -0.17 & -0.09 \\
\hline BORER.10 & 0.17 & 0.34 & 0.17 & 0.30 & 0.19 & 0.42 & -- & 0.72 & 0.66 & 0.63 \\
\hline BORER. 12 & 0.16 & 0.19 & 0.23 & 0.16 & 0.20 & 0.24 & 0.43 & -- & 0.82 & 0.85 \\
\hline RIDGES.12 & 0.23 & 0.24 & 0.32 & 0.22 & 0.24 & 0.30 & 0.43 & 0.95 & --- & 0.50 \\
\hline EXITS. 12 & 0.23 & 0.24 & 0.32 & 0.22 & 0.24 & 0.30 & 0.43 & 0.95 & 1.00 & --- \\
\hline \multicolumn{11}{|c|}{ European white birch } \\
\hline
\end{tabular}


Table 5. Factor analysis of 10 variables measured in a plantation of paper and European white birch in southern Michigan.

\begin{tabular}{|c|c|c|c|c|c|c|c|c|c|c|c|c|}
\hline \multicolumn{3}{|c|}{ Eigen value summary } & & & & & & & & & & \\
\hline \multirow{2}{*}{$\begin{array}{c}\text { Factor } \\
\text { no. }{ }^{y}\end{array}$} & \multirow{2}{*}{$\begin{array}{l}\text { Eigen } \\
\text { value }^{\mathbf{x}}\end{array}$} & \multirow{2}{*}{$\begin{array}{c}\text { Cumulative } \\
\text { percent } \\
\text { variation } \\
\text { explained }\end{array}$} & \multicolumn{10}{|c|}{ Eigen vector summary: rotated factor loadings ${ }^{2}$} \\
\hline & & & HT.2 & HT.6 & HT.10 & DBH.7 & BARK.6 & BARK.8 & BORER.10 & BORER.12 & RIDGES.12 & EXITS.12 \\
\hline 1 & 4.5 & 46 & 0.4 & $0.9^{*}$ & $0.9^{*}$ & $0.9^{*}$ & 0.4 & 0.3 & -0.1 & -0.2 & -0.2 & -0.1 \\
\hline 2 & 2.9 & 74 & -0.1 & -0.1 & -0.2 & -0.1 & 0.0 & 0.1 & $0.6^{*}$ & $0.9^{*}$ & $0.5^{*}$ & $1.0^{*}$ \\
\hline 3 & 0.7 & 82 & 0.1 & 0.2 & 0.2 & 0.2 & $0.9^{*}$ & 0.2 & 0.0 & 0.0 & 0.0 & 0.0 \\
\hline 4 & 0.5 & 86 & 0.1 & 0.2 & 0.2 & 0.2 & 0.2 & $0.9^{*}$ & 0.1 & 0.0 & 0.0 & 0.0 \\
\hline 5 & 0.5 & 91 & $0.9^{*}$ & 0.3 & 0.1 & 0.2 & 0.1 & 0.1 & 0.0 & -0.1 & 0.0 & -0.1 \\
\hline 6 & 0.4 & 95 & 0.0 & 0.1 & 0.1 & 0.1 & 0.0 & 0.0 & -0.3 & -0.4 & $-0.8^{*}$ & -0.1 \\
\hline 7 & 0.3 & 98 & 0.0 & 0.0 & 0.1 & 0.0 & 0.0 & 0.0 & $-0.7^{*}$ & -0.1 & -0.2 & -0.1 \\
\hline 8 & 0.1 & 99 & 0.0 & 0.0 & 0.3 & -0.2 & 0.0 & 0.0 & 0.0 & 0.0 & 0.0 & 0.0 \\
\hline 9 & 0.1 & 99 & 0.0 & -0.2 & 0.2 & 0.0 & 0.0 & 0.0 & 0.0 & 0.0 & 0.0 & 0.0 \\
\hline 10 & 0.1 & 100 & 0.0 & 0.0 & 0.0 & 0.0 & 0.0 & 0.0 & 0.0 & -0.2 & 0.0 & 0.1 \\
\hline
\end{tabular}

${ }^{2}$ Rotated factor loadings $>0.5$ contribute substantially to the factor $\left({ }^{*}\right.$ above $)$. Traits described in detail in text.

y The contributions of factors 4 through 10 are negligible in explaining the variation in the sample.

xThe Eigen value represents the equivalent number of single variables represented by each factor.

bronze birch borer, European white birch appears to be an unacceptable white-barked birch species for use in landscape and other plantings due to its susceptibility to borer attack. Many other birch species have been tested for borer resistance, but results have been ambiguous. In northeastern North America, native paper birch offers a potential alternative, as it possesses adequate variation of growth traits, bark color, and borer resistance to sustain selection and breeding for these characters. This investigation identifies several half-sib families of paper birch that grow more quickly than the European white birch average, are unaffected by bronze birch borer at age 12, and have bark color at age 6 equivalent to the average 8-year-old European white birch. Individuals within these paper birch families have been identified that surpass the average European white birch tested for these three traits. The measured growth, bark color, and borer resistance traits were correlated in such a way as to facilitate future selection and breeding. While the data reported here indicate that the range and nature of genetic variation in these traits present opportunities for the rapid improvement of this species for landscape use, paper birch's adaptability to urban and suburban environments is largely untested. Future studies should evaluate paper birch's performance outside its natural range, particularly in urban and suburban environments. Additionally, multiple-site studies containing larger family samples would be useful in determining the significance of family $\mathrm{x}$ environment interaction and providing more precise variance component" and heritability estimates to guide future selection efforts.

\section{Literature Cited}

Anderson, R.F. 1944, The relation between host condition and attacks by the bronze birch borer. J. Econ. Ent. 37:589-596.

Ball, J. and G. Simmons. 1980. The relationship between bronze birch borer and birch dieback. J. Arboriculture 6:309-314.

Ball, J. and G; Simmons. 1986. The influence of host condition on post first instar development of the bronze birch borer, Agrilus anxius (Coleoptera:Buprestidae). Great Lakes Ent. 19:73-76.

Clausen, K.E. 1968. Ornamental potential in the birches. Proc. 6th Central States For. Tree Imp. Conf. p. 21-23.

Clausen, K.E. and P.W. Garrett. 1969. Progress in birch genetics and tree improvement. Birch Symp. Proc., U.S. Dept. Agr. For. Serv. Northeastern For. Expt. Sta., Durham, N.H. p. 87-94.

Dirr, M.A. 1981. White-barked birches, borers and alternatives. Weeds Trees \& Turf 20(2):51, 54.

Hannah, P.R. 1987. Early growth of planted yellow and paper birch and European birches in Vermont. New For. 4:343-349.

Hanover, J.W. 1975. Physiology of tree resistance to insects. Annu. Rev. Ent. 20:75-95.

Hintze, J.L. 1987. Number Cruncher Statistical System, Ver. 5.0 user's manual. Jerry L. Hintze, Kaysville, Utah.

Kozel, P.C. and R.C. Smith. 1976. A disease-resistant white birch from Japan is introduced for landscape use. Horticulture 54(1):36.

Kozel, P.C. and E.K. Toth. 1975. Birch trees for landscape use. Amer. Nurseryman 145(6):7-10.

Mattson, W. J., and R.A. Haack. 1987. The role of drought in outbreaks of plant-eating insects. Bioscience 37:110-118.

Panshin, A.J. and C. deZeeuw. 1980. Textbook of wood technology. McGraw-Hill, New York.

Reed, C. 1985. A birch's beauty is more than skin-deep. Horticulture 63(9):22-29.

Santamour, F. S., Jr. 1982. Which white birches are least susceptible to bronze birch borer? Amer. Nurseryman 156(11):61-63.

Santamour, F. S., Jr., and K.E. Clausen. 1979. Testing the Japanese white birch. Amer. Nurseryman 149(1): 15-21.

SAS. 1985. SAS user's guide: statistics, version 5 (cd.). SAS Institute, Inc. Cary, N.C.

Sohasky, M.F. 1977. Genetic variation of seed and seedling characteristics of paper birch (Betula papyrifera) and European white birch (Betula verrucosa). MS Thesis, Michigan State Univ., East Lansing.

Wilson, L.F. and R.A. Haack. 1990. The bronze birch borer. U.S. Dept. Agr. For. Serv., North Central For. Expt. Sta., Northern Hardwood Note 7.09.

Wright, J.W. 1976. Introduction to forest genetics. Academic, New York. 